\title{
IN VITRO EVALUATION OF THE ANTIMICROBIAL POTENTIAL ASSOCIATION OF SCHINUS TEREBINTHIFOLIUS RADDI AND SYZYGIUM AROMATICUM L.
}

\author{
Jaqueline A. Machado, ${ }^{1}$ Marcia A.Rebelo, ${ }^{1}$ Laura I.L. Favaro, ${ }^{1}$ Marta M.D.C. Vila, ${ }^{2}$ and \\ Marli Gerenutti ${ }^{2}$ \\ ${ }^{1}$ Pharmacology Department, School of Pharmacy of University of Sorocaba, Sorocaba, São Paulo, Brazil \\ ${ }^{2}$ Phamacology Department, Master of Pharmacy of University of Sorocaba, Sorocaba, São Paulo, Brazil
}

\begin{abstract}
The use of vegetable preservatives as inputs in cosmetics has been increasing worldwide and the research with these herbal drugs are of great relevance. Thus, this study/research evaluated the antimicrobial potential of the combination/association of the lyophilized powder of the bark of Schinus terebinthifolius Raddi and the essential oil of the Syzygium aromaticum L. as an alternative to the use of parabens in $\mathrm{O} / \mathrm{W}$ emulsion. The antibacterial and antifungal sensitivity of the association of the lyophilized powder of Schinus terebinthifolius Raddi and the essential oil of the Syzygium aromaticum L was determined by the diffusion disk technique method. The final result/obtained served/ as parameter for an incorporation of 5\% of each vegetable drug in the emulsion as preservative system. The pharmaceutical preparation containing combination of herbal drugs was subjected to the "Challenge Test" against Staphylococcus aureus, Escherichia coli, Pseudomonas aeruginosa, Candida albicans and Arpesgillus brasilienses which showed to be a powerful or leading preservative.
\end{abstract}

Keywords: Antimicrobial activity, Challenge test, Schinus terebinthifolius Raddi, Syzygium aromaticum L,Vegetable preservatives.

\section{INTRODUCTION}

The Schinus terebinthifolius Raddi belongs to the botanical family Anacardiaceae. It is represented by 70 genera and 600 species of trees or shrubs, known to be fruitful and presenting good wood quality. It is of pantropical occurence, including a few representatives in temperate regions, is native to South America, especially in Brazil, Argentina and Paraguay [1]. The study of the aqueous extract of the leaves of the Schinus terebinthifolius Raddi presents an antimicrobial activity against $S$. aureus, B. subtilis, E. coli, P. aeruginosa, T. rubum, M. canis, E. floccosum and Bacillus cereus [2]. The presence of tannins and other various substances such as terebintine, terebinthifolius acid, ursolic acid, and lower concentration of alkaloids, chalcones and urundeuvidinas possibly gives Schinus terebinthifolius Raddi the antibacterial and antifungal activity [3].The Sygium aromaticum L. belongs to the Myrtaceae family, native to the Moluccas Island, Indonesia, and their growth occurs in tropical climates [4]. The clove is the dried flower bud of Syzygium aromaticum L., and eugenol (phenol- 83.75\%) is its major constituent [5]. It presents bactericide action against the bacteria Vibiro spp, Edwardsiella spp, Aeromonas spp, Escherichia coli and Staphylococcus aureus [6]. And fungal growth on the micellar C. albicans [7]. The purpose of this study is the association of Schinus terebenthifolius Raddia and Syzygium aromaticum L when incorporated into the emulsion.

\section{MATERIAL AND METHODS}

\subsection{Preparation of lyophilized powder of Schinus terebinthifolius Raddi.}

An amount of 493 grams of the powder from the bark of Schinus terebinthifolius Raddi was left soaking in hydroalcoholic solvent at $77 \%(\mathrm{v} / \mathrm{v})$ the solvent was changed ef every 24 hours for 5 times. Through rotary evaporation process the solvent was removed, the aqueous extract obtained was frozen for 48 hours. Obtaining a yield of frozen and lyophilized for 48 hours. Obtaining a yield of 42 grams.

\subsection{Essential oil of Syzygium aromaticum L.}

The essential oil used was manufactured by the company Aromax Industry and Trade Ltd., under the batch number 101034775- Manufacture Date 10/18/2010.

\subsection{Determination of Total Polyphenols (TP).}

The procedure was performed in triplicate, in the test tube were added $2 \mathrm{~mL}$ of LSS/ Triethanolamine, $1 \mathrm{~mL} \mathrm{of} \mathrm{FeCl} \mathrm{m}_{3}$ and 1 $\mathrm{mL}$ water extract of the bark of the lyophilized powder Schinus terebinthifolius Raddi 5 grams/100 $\mathrm{mL}$ at a concentration of 5:100 Schinus terebinthifolius Raddi, were performed after 15 minutes. The absorbance reading were at the wavelength of $510 \mathrm{~nm}$. It was calculated as percentage of total phenolics with the equation 1 using tannic acid as standard.

Where:

$$
\mathrm{P}_{\mathrm{T}}(\% \mathrm{~m} / \mathrm{m})=\mathrm{C}_{\mathrm{A}} \times \mathrm{FD}_{\mathrm{A}} \times 100 \quad \text { [Equation 1] }
$$


$\mathrm{P}_{\mathrm{T}}(\% \mathrm{~m} / \mathrm{m})=$ Percentage of the weight of total polyphenol. $\mathrm{C}_{\mathrm{A}}=$ Value corresponding to the sample concentration in $\mathrm{mg} / \mathrm{mL}$ according to the equation result of tannic acid standard curve. $\mathrm{FD}_{\mathrm{A}}=$ Dilution factor of the sample

\subsection{Determination of Total Tannins (TT).}

The procedure was performed in triplicate, in the test tube were added $2 \mathrm{~mL}$ of albumin solution and $1 \mathrm{~mL}$ of the aqueous extract of the powder of Schinus terebinthifolius Raddi, and this was centrifuged for 15 minutes, the supernatant was discarded. It was added $4 \mathrm{~mL}$ of LSS/ Triethanolamine, $1 \mathrm{~mL}$ of $\mathrm{FeCl}_{3}$. After 15 minutes, readings of absorbance were taken at a wavelength of $510 \mathrm{~nm}$. With the equation 2 it was possible to calculate the Total Tannins, using tannic acid, and albumin as standard.

$\mathrm{T}_{\mathrm{T}}(\% \mathrm{~m} / \mathrm{m})=\mathrm{C}_{\mathrm{A}} \times \mathrm{FD}_{\mathrm{A}} \times 100 \quad$ [Equation 2]

Where:

$\mathrm{T}_{\mathrm{T}}(\% \mathrm{~m} / \mathrm{m})=$ Percentage of the weight of the tannins. $\mathrm{C}_{\mathrm{A}}=$ Value corresponding to the sample concentration in $\mathrm{mg} / \mathrm{mL}$ according to the equation result of tannic acid standard curve. $\mathrm{FD}_{\mathrm{A}}=$ Dilution factor of the sample

2.5 Identification of eugenol by Thin Layer Chromatography.

Separate dilutions of $20 \mu \mathrm{L}$ of the essential oil of Syzygium aromaticum L. and $20 \mathrm{~mL}$ of eugenol pattern (Merck) were made in $2,0 \mathrm{~mL}$ of toluene; the phase used as mobile phase was the toluene, and spread with a solution of anisic aldehyde in methanol $\left(10\right.$ minutes at $\left.105^{\circ} \mathrm{C}\right)$; as a developer a solution of sulfuric acid was used [8].

2.6 Determination of antibacterial and antifungal sensitivity in the association of Schinus terebinthifolius Raddi and Syzygium aromaticum $\mathbf{L}$.

The lyophilized powder of Schinus terebinthifolius Raddi was solubilized in propylenegycol $+0.05 \%$ Polysorbate 80. The solutions with the two drugs were prepared in the following vegetable concentrations of $20 \%, 30 \%, 40 \%, 50 \%$, $60 \%, 70 \%$; In addition, a solution with pure essential oil $(100 \%)$ and another with the lyophilized powder in $80 \%+0.05 \%$ of Polysorbate 80 were prepared. The filter paper disks were impregnated with $10 \mu \mathrm{L}$ of test solutions (5 $\mu \mathrm{L}$ Schinus terebinthifolius Raddi $+5 \mu \mathrm{L}$ Syzygium aromaticum L.) and were applied in a petri dish containing agar medium HiltonMuller (bacteria) and Sabouraud Dextrose Agar (fungi) previously seeded with bacterial suspensions (Pseudomonas aeruginosa ATCC 27853, Staphylococcus aureus ATCC 25923 and Escherichia coli ATCC 25922). Turbidity adjusted to 0.5 McFarland scale; A. brasilienses fungal suspension of ATCC 16404, adjusted by the absorbance reading (from 0.09 to 0.11 ) and transmittance at $530 \mathrm{~nm} 80-82 \%$ plus $0.01 \%$ Polysorbate 20, and C. albicans ATCC 10231 in absorbance at $625 \mathrm{~nm}$ (0.08 till 0.10) [9]. The following controls were performed: negative control (used solvent), positive control (antibiotic for Gram + and Gram -, antifungal -, ketoconazole), viability of the microorganism, purity of the medium.

\subsection{Challenge test of the preservative system ("Challenge Test")}

A transfer of $50 \mu \mathrm{L}$ of fungal and bacterial suspension was done to packages containing $30 \mathrm{~g}$ of $\mathrm{O} / \mathrm{W}$ emulsion in which 5\% powder of Schinus terebinthifolius Radd and the essential oil of Syzygium aromaticum L. had been incorporated. By removing $1 \mathrm{~g}$ of each sample that was diluted in a test tube containing $9 \mathrm{~mL}$ of $0.9 \%$ saline solution, resulting in a $10-1$ dilution, after a dilutions series the final dilution of $10^{-5}$ was obtained. Plating was performed in duplicate dilutions of $10^{-4}$ and $10^{-5}$, by the diffusion technique on solid media "pour plate" using Tryptone Soy Agar inactivant $+(0.05 \%$ lecithin and $1 \%$ Polysorbate 80$)$ for bacteria and Sabouraud Dextrose Agar + inactivant (0.05\% lecithin and 1\% Polysorbate 80$)$ for fungi. A counting of CFU was made after the incubation. The procedure was realized/performed/done at the following time periods: t0, 24, 48 and 7, 14, 21 and 28 days. The following controls were performed: control of purity of the medium control and viability of the microorganism [10].. The log reduction calculation was possible from the procedure of colony counts:

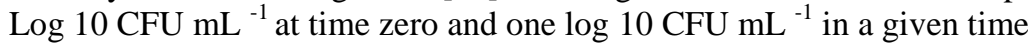

\section{RESULTS AND DISCUSSION}

Providing products that reduce the risk of toxicity and that at the same time are obtained from natural and renewable sources, becomes an economically viable option and meet the growing demand for products containing natural inputs. Therefore, investigation of new herbal drugs which present antimicrobial activity, besides meeting this demand provides alternatives for the treatment of diseases involving the action of microorganisms. The choice of lyophilized powder from the bark of Schinus terebintifolius Raddi as a raw material, was based on the physical chemistry of good solubility, low humidity and high concentration of tannin, favoring the incorporation into the $\mathrm{O} / \mathrm{W}$ emulsion and contributing to the antimicrobial action [2]. The essential oil of Syzygium aromaticum L. antimicrobial activity has already been proved, mainly against fungi, due to high concentration of eugenol presence in this component [5], this was the determining factor for the choice in addition to the characteristic of the $\mathrm{O} / \mathrm{W}$ emulsion in which the oil phase is surrounded by the water phase, this way protecting the volatile essential oil and avoiding the thereof loss during its use [11]. The present determination of polyphenols and tannins in lyophilized powder was performed using the methodology proposed by Mole [12] with some adaptations, and the quantification of the activity was calculated based on the standard curve of tannic acid and albumin respectively. This dosing technique is based on the capacity that tannin has of complexing with proteins, thus allowing the separation of the tanning present in the extract. 
IOSR Journal of Pharmacy

Vol. 2, Issue 3, May-June, 2012, pp.438-443

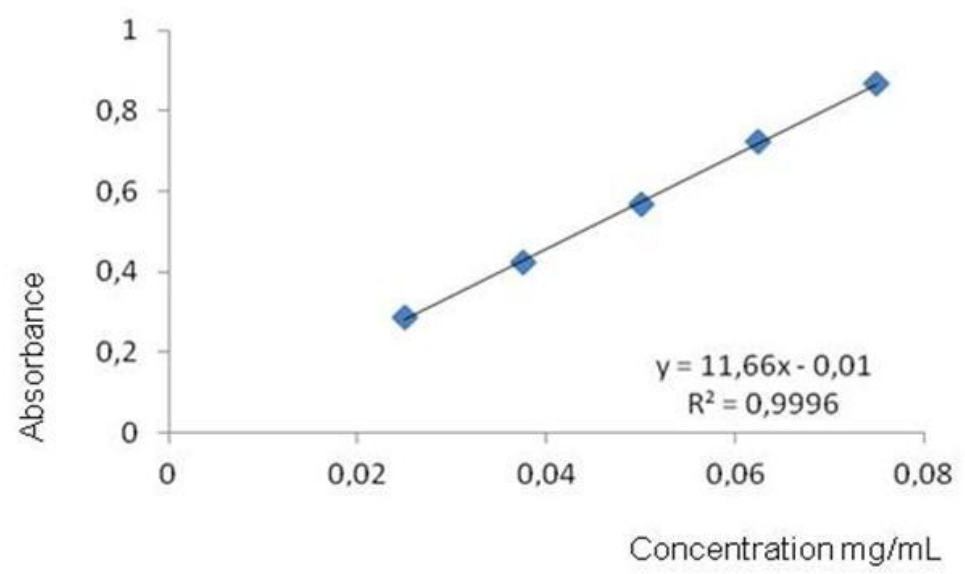

Figure 1: Tannic Acid standard curve to determine the concentration of phenolic compounds contained in the lyophilized powder of Schinus terebinthifolius Raddi.

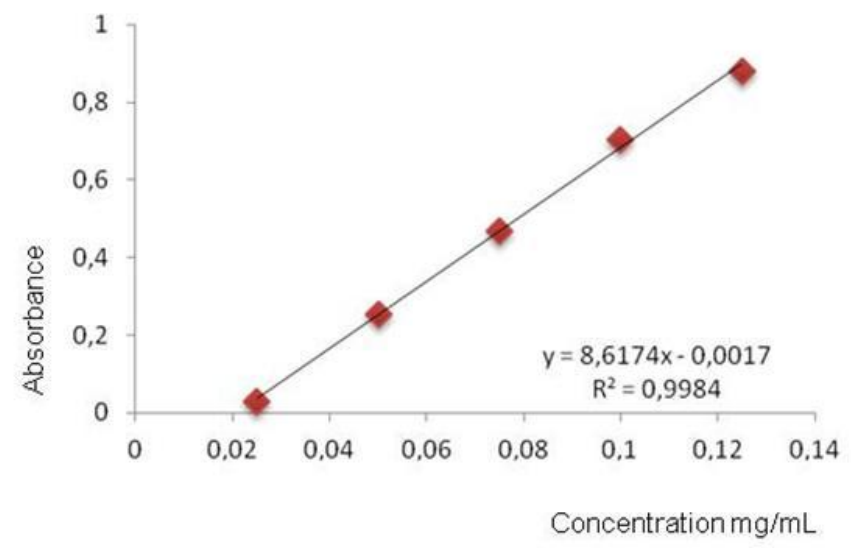

Figure 2: Tannic Acid standard curve and albumin to determine the concentration of tannins contained in the lyophilized powder of Schinus terebinthifolius Raddi.

The yield of $14.09 \%$ and $25.69 \%$ of tannins and polyphenols respectively extracted demonstrated that the technique of lyophilization provided a better extraction of secondary metabolites of interest. While the techniques of maceration in an aqueous solvent used for Silva [13] which resulted in a content of $11.01 \%$ tannin, and hydroalcoholic solvent soaking in $70 \%$ (v/v) [14] resulted in 7.88\% total poliphenols and 6.61\% of total tannins. Pansera studies [15] showed levels of tannins $11 \%$, $10 \%$ and $16 \%$ for Angelica archangelica (leaves), Rosmarinus officinalis and Cinnamomum champora, respectively. Our analysis indicated that the Schinus terebinthifolius Raddi is a good source of tannin. The quality of the essential oil Syzygium aromaticum L. acquired, was evaluated by the technique of thin layer Chromatography which standard is the essential oil eugenol (Merck), when the refractive index of $0.48\left(\mathrm{R}_{\mathrm{f}}\right)$ was obtained after measuring tape and compared to the Portuguese Pharmacopeia, confirming the authenticity and quality of the oil used [9].The antimicrobial activity of the association of the powder from the bark of Schinus terebinthifolius Raddi and the essential oil of Syzygium aromaticum L. was analyzed by standardized disk diffusion by NCCLS [10], this method checks the sensitivity of certain microorganism to potentially bactericidal or bacteriostatic substances, and for this purpose, we used the microorganisms recommended by the Brazilian Pharmacopeia [16] for inputs to be used as a preservative in pharmaceutical formulations and/or cosmetic. The results are shown in Table 1. 
Table 1: Antibacterial and antifungal sensitivity activities of the association of Schinus terebinthifolius Raddi and Syzygium aromaticum L. average of inhibition zones ( $\mathrm{mm}$ ) of the disk diffusion test

\begin{tabular}{|c|c|c|c|c|c|c|}
\hline \multirow[b]{2}{*}{ SUBSTANCE } & \multirow[b]{2}{*}{$\begin{array}{c}\text { CONCENTRATION } \\
(\%)\end{array}$} & \multicolumn{2}{|c|}{ BACTERIAL SPECIES } & \multicolumn{3}{|c|}{ FUNGAL SPECIES } \\
\hline & & S. aureus & E.coli & P.aeruginosa & C.albicans & A.brasilienses \\
\hline & 20 & 7 & $\mathrm{R}$ & $\mathrm{R}$ & $\mathrm{R}$ & $\mathrm{R}$ \\
\hline S.terebinthifo & 30 & 7 & $\mathrm{R}$ & $\mathrm{R}$ & $\mathrm{R}$ & $\mathrm{R}$ \\
\hline lius Raddi & 40 & 12 & $\mathrm{R}$ & 7 & $\mathrm{R}$ & $\mathrm{R}$ \\
\hline+ & 50 & 13 & 5 & 7 & $\mathrm{R}$ & $\mathrm{R}$ \\
\hline S.aromaticum & 60 & 16 & 7 & 10 & $\mathrm{R}$ & $\mathrm{R}$ \\
\hline \multirow[t]{2}{*}{$L}$. & 70 & 17 & 10 & 12 & 9 & 8 \\
\hline & $80 / 100$ & 22 & 14 & 15 & 11 & 11 \\
\hline \multirow{4}{*}{$\begin{array}{l}\text { Negative } \\
\text { Control }\end{array}$} & DMSO & $\mathrm{R}$ & $\mathrm{R}$ & $\mathrm{R}$ & $\mathrm{R}$ & $\mathrm{R}$ \\
\hline & Propylene glycol & $\mathrm{R}$ & $\mathrm{R}$ & $\mathrm{R}$ & $\mathrm{R}$ & $\mathrm{R}$ \\
\hline & Polysorbate 80 & $\mathrm{R}$ & $\mathrm{R}$ & $\mathrm{R}$ & $\mathrm{R}$ & $\mathrm{R}$ \\
\hline & Mineral oil & - & - & - & $\mathrm{R}$ & $\mathrm{R}$ \\
\hline \multirow[t]{2}{*}{$\begin{array}{l}\text { Positive } \\
\text { Control }\end{array}$} & $\begin{array}{c}\text { CPM, CFO, } \\
\text { CTX, CRO, } \\
\text { AMC, ATM, } \\
\text { AMI, AMP, } \\
\text { CAZ, CIP, SUT, } \\
\text { CLO, GEN, } \\
\text { TET, TOB, CLI, } \\
\text { ERI, OXA, PEN, } \\
\text { VAN.* }\end{array}$ & ATM - R & - & $\begin{array}{c}\text { CFO, AMC, } \\
\text { AMP, CLO, } \\
\text { SUT - R }\end{array}$ & - & - \\
\hline & Cetoconazol & - & - & - & $\mathrm{R}$ & $\mathrm{R}$ \\
\hline Feasibility & & feasible & feasible & feasible & feasible & feasible \\
\hline $\begin{array}{l}\text { Purity of the } \\
\text { médium }\end{array}$ & & NG & NG & NG & NG & NG \\
\hline
\end{tabular}

* (CPM) Cefepime, (CFO) Cefoxitin, (CTX) Cefotaxime, (CRO) Ceftriaxone, (AMC) Amoxacilina+ Clavulanic Acid, (ATM) Aztreonam, (AMI) Amikacin, (AMP) Ampicillin, (CAZ) Ceftazidime, (CIP) Ciprofloxacin, (SUT) Cotrimoxazole, (CLO) Chloranphenicol, (GEN) Gentamicin, (TET) Tetraciclyne and (TOB) Trobamicin, (CLI) Clindamycin, (ERI) Erytromycin, (OXA) Oxacilin, (PEN) Penicilin G, (VAN) Vancomycin. (NG) No growth

It can be observed that the bacteria are more sensitive to the lyophilized powder Schinus terebinthifolius Raddi and the essential oil Syzygium aromaticum L., specially S. aureus in the concentration of $80-100 \%$ (medium halo of $22.0 \mathrm{~mm}$ ), result also obtained by Pereira [6] where the zone of inhibition was higher for S. aureus (15 mm) than for E. coli (12 mm) in concentration of 50\% of essential oil of Syzygium aromaticum L. Silva [17] presented inhibition of halos of 0,095 for S. aureus (ATCC 25923) and 0,089 for E. coli (ATCC 25922), using a concentration of 3\% of the oil. The antimicrobial action of Schinus terebinthifolius Raddi was also evaluated by Lima [2], the aqueous extract was used in a concentration of 5000 $\mathrm{mg} / \mathrm{mL}$, where the zone of inhibition of $S$. aureus was $11 \mathrm{~mm}$, for E. coli there was no growth, for P. aeruginosa was $12 \mathrm{~mm}$ and for $C$. albicans $14 \mathrm{~mm}$. The methodology used for these studies was the diffusion in solid. The control of the solvents showed that they do not interfere in the antimicrobial action. Therefore DMSO helps the dispersion of the essential oil, avoiding [14] formation with active variations . Regarding the positive control used, the Aztreonam, Ketoconazole, Cefoxitin, Amoxicillin, Ampicillin, Chloramphenicol and Cotrimoxazole showed resistance to certain microorganisms, suggesting that the tested plant inputs have a great potential for therapeutic use in microorganisms that may exhibit resistance to the afore mentioned antibiotics. Results show that the synergistic use of two plant species, present a bactericidal concentration of $50 \%$ and bactericide/fungicide to $70 \%$, where the differences in the sizes of the halos shown in previous studies, may be the result of the methodology adopted for extraction of assets, especially when they use herbal drugs. For such studies we need to consider the complexity of its composition, even though the dosing study conducted has shown that the lyophilized powder of Schinus terebinthifolius Raddi has a good tannin content, antimicrobial substance, and that the essential oil of Syzygium aromaticum L., has $83 \%$ of eugenol that is proved to be an antifungal substance, however, we cannot disregard the possibility of another secondary metabolites collaborating with antimicrobial activity.

For the evaluation of preservative system containing the lyophilized powder of the bark of Schinus terebinthifolius Raddi and the essencial oil of Syzygium aromaticum L. O/W emulsion was chosen, which contains raw materials that are 
known to have antimicrobial activity, avoiding that any component present in the formulation may interfere with or potentiate the action of the antimicrobial preservative. To ensure the suitability of the results obtained in the challenge test, an emulsion containing the same components was prepared without the presence of the preservative system test, proceeding with the artificial contamination and with the same analysis that were done with the test formulation. Following the recommendation of the Technical University [18] it was verified the concentration which presented the inhibition of the tested microorganisms. By the average diameter of the halos of inhibition, the percentage of 5\% was determined and the average of the inhibition halos diameters presented in sensitivity test was calculated. The concentration of 5\% of the powder of Schinus terebenthifolius Raddi and essencial oil of Syzygium aromaticum L. which was incorporated in the O/W emulsion was obtained by calculating the mean diameter of the halos of inhibition presented by five microorganisms in a concentration of $70 \%$, as recommended by the Technical University [18]. According to Orth [19] it is necessary to verify whether the incorporated preservative has the capacity of keeping the formulation free of microbial contaminations. In regards to this purpose it is necessary to perform the challenge test, which consists of artificially contaminating the formulation where new preservative system has been incorporated with certain microorganisms, adopting the methodology preconized by the Brazilian Pharmacopeia [16] using S. aureus, E. coli, P. aeruginosa, C. albicans and A. brasilienses. microorganisms. The analyses of possible growth and survival of the microorganisms were performed in 24 hours, 7, 14, 21 and 28 days. The result compared to the number of colonies forming units (CFU), formed in the previous time, and having to present according to the chosen methodology, a decrease of at least $90 \%$ at each reading. For the evaluation of preservative system containing the lyophilized powder of bark of the Schinus terebinthifolius Raddi and the essencial oil of Syzygium aromaticum L. the O/W emulsion was chosen, which contains raw materials that are known not to have antimicrobial activity, thus avoiding that any component present formulation may interfere with or potentiate the antimicrobial preservative . In order to ensure the suitability of the results obtained in the challenge test, an emulsion containing the same components was prepared without the presence of the preservative test system, proceeding to the same analysis and artificial contamination carried out using the test formulation.Following to the established criteria by the Brazilian Pharmacopeia [16] the effectiveness of the preservative plant by counting the CFU formed in the time mentioned above was evaluated, though the reduction of 3 logarithmic cycles in 7 days. No changes in 14 days which shall remain till the $28^{\text {th }}$ day for the bacteria and for the fungus, a reduction of 2 logarithmic cycles in 14 days and no increase until the $28^{\text {th }}$ day.The first reading was taken 24 hours after the contamination of the $\mathrm{O} / \mathrm{W}$ emulsion, it is found that the vegetable preservative system did not show any fungal or bacterial growth and the non preservative formulation had significant formulation CFUs it was observed that the control showed no contamination of the medium control and showed an increase viability of the microorganisms used.The analysis were done till the end of the time period determined by the adopted methodology (28 days). The results are unchanged. A similar result was found by Moura [14] using extract of Schinus terebinthifolius Raddi using the hydroalcoholic extract in a gel formulation containing also parabens preservative system. With the exception of the test with the fungus A. Brasilia had three cycles of the decay log only from the analysis performed on the $14^{\text {th }}$ day. In this way, its evidenced the bacterial action and broad spectrum of antifungal preservative system containing the combination of the powder from the bark of the Schinus terebintifolius Raddi and the essencial oil of Syzygium aromaticum L. and the incorporation of the essential oil favored including the antifungal inhibiting the growth of $A$. brasilienses.

\section{CONCLUSION}

Based on these results, we can conclude that the action of the vegetable preservative system was effective it can be conserved as an applicable substitution of the parabens in pharmaceutical formulations such as $\mathrm{O} / \mathrm{W}$ emulsion, and that the synergistic use of the lyophilized powder of bark of Schinus terebinthifolius Raddi and the essential oil of Syzygium aromaticum $\mathrm{L}$ potentiates their antifungal effect, and probably the antimicrobial drugs presented by these plants, due to the presence of tannin and eugenol. 


\section{REFERENCES}

[1] H. Lorenzi, F.J.A. Matos. Plantas medicinais no Brasil: nativas e exóticas (Nova Odessa, SP: Instituto Plantarum de Estudos da Flora, 2002).

[2] E.O. Lima, F.O. Perera, I.O. Lima, V.N. Trajano and E.L. Souza, Schinus terebintifolius Raddi - evaluation of the spectrum of antimicrobial activity of an aqueous extract, Informativo Profissional do Conselho de Farmácia Federal, Infarma, 16(7-8), 2004.

[3] M.J.M. Guerra, M.L. Barreira, Z.M. Rodríguez and Y. Rubalcaba, Actividad antimicrobiana de um extracto fluido Al 80\% de Schinus terebinthifolius Raddi (Copal), Revista Cubana Plantas Medicinais, 5(1), 2000, 2325.

[4] R.A. Oliveira, T.V. Reisi, C.K. Sacramento, L.P. Duarte and F.F. Oliveira, Volatile chemical constituents of spices rich in eugenol, Brasilian Journal of Pharmacognosy, 19(3), 2009, 771-775.

[5] R. Scherer, R. Wagner, M.C.T. Duarte and H.T. Godoy, Composition and antioxidant and antimicrobial activities of clove, citronella and palmarosa essential oils, Brazilian Journal of Medicinal Plants, 11(4), 2009, 442-449.

[6] A.A. Pereira, M.G. Cardoso, L.R. Abreu, A.R. Morais, L.G.L. Guimarães and A.P.S.P. Salgado, Chemical ckaracterization and inhibitory effect of essential oils on the growth of Staphylococcus aureus and Escherichia coli, Science and Agrotechnology, 32(3), 2008, 887-893.

[7] I. Ahmad and A.Z. Beg, Antimicrobial and phytochemical studies on 45 Indian medicinal plants again multidrug resistant human pathogens, Journal of Ethnopharmacology, 74, 2001, 113-123.

[8] K.C. Srivastava and N. Malhotra, Acetyl eugenol, a component of oil of cloves (Sygium aromaticum L) inhibits aggregation and alters arachidonic acid metabolism in human blood platelets, Prostaglandins Leukot. Essent.Fatty Acids, 42, 1991, 73-81.

[9] Farmacopeia portuguesa VII: edição oficial. 7. ed. (Lisboa, Portugal: Rainho \& Neves, 2002).

[10] NCCLS. Standardization of antimicrobial susceptibility testing and by disk diffusion, 23(1), 2003.

[11] R.C.C. Frange, M.T. Garcia and E. Michael, Development of emulsions olive oil-in-water: evaluation of physical stability, Journal of Basic and Applied Pharmaceutical Sciences, 30(3), 2009, 263-271.

[12] S. Mole, A critical analysis of techniques for measuring tannins in ecological studies, Oecologia, 72, 1987, 148156.

[13] P.E.R. Silva, Physico-chemical, biological, validation of analytical methods and development of semi-solid pharmaceutical form of extract from the beach aroeirada (Schinus terebinthifolius Raddi), master diss., State University of Maringá Paraná, 2009.

[14] T.F.A. Moura, F.N. Raffn and A.L. Santos, Evaluation of a preservative system in a gel containing hydroalcoholic extract of Schinus terebinthifolius, Brasilian Journal of Pharmacognosy, 21(3), 2011, 532-536.

[15] M.R. Pansera, A.C.A. Santos, R. Wasun, M. Rosato, L.D. Rota, G.F PaulettI and L.A. Serafini, Determination of tannin total content in aromatic and medicinal plants cultivated in Northern Rio Grande do Sul State, Brazil,Brasilian Journal of Pharmacognosy, 13(1), 2003, 17- 22.

[16] Farmacopéia Brasileira, $5^{\mathrm{a}}$ ed. (Brasília, DF, 2010) <http://www.anvisa.gov.br/hotsite/farmacopeia/index.htm >. Acesso em: 01 de março de 2011.

[17] M.T.N. Silva, P.I. Ushimaru, L.N. Barbosa, M.L.R.S. Cunha and A. Fernandes-Júnior, Antibacterial activity of plant essential oils against Staphylococcus aureus and Escherichia coli strains isolated from human specimens,Brazilian Journal of Medicinal Plants, 11(3), 2009, 257-262.

[18] I.S. Correia, Quantification of antimicrobial activity. Technical University (http://www.eescola.pt/topico.asp?id=368)

[19] D.A. Orth, Linear regression method for rapid determination of cosmetic preservative efficacy, Journal of the Society of Cosmetic Chemists, 30(6), 1979, 321-332. 